\title{
LIPID PEROXIDATION AND SEED EMERGENCY IN PROGENIES OF THE YELLOW PASSION FRUIT PLANT ${ }^{1}$
}

\author{
JOÃO PAULO BESTETE DE OLIVEIRA², RODRIGO SOBREIRA ALEXANDRE ${ }^{3}$, \\ JACSON RONDINELLI DA SILVA NEGREIROS ${ }^{4}$, JOSÉ CARLOS LOPES ${ }^{5}$, \\ CLAUDIO HORST BRUCKNER ${ }^{6}$
}

\begin{abstract}
The objective was to evaluate the percentage of emergency plantlets and lipid peroxidation in seeds of 29 half-sib progenies of yellow passion fruit (Passiflora edulis Sims.) after 24 months under storage. The experimental design was completely randomized, with four replications of 50 seeds each, from which the treatments were the progenies (1-29). The evaluation of the percent plantlet emergency was accomplished at 14 and 28 days after sowing. The lipid peroxidation of the seeds was expressed as malondialdehyde (MDA) content that was determined by the TBARS method. Approximately $21 \%$ of those half-sib progenies maintained the viability of their seeds for twenty-four months under storage. The results point out a remarkable genetic variability for vigor and emergency of the yellow passion fruit plantlets, with occurrence of individuals with high and other ones with low capacity to maintaining the physiologic quality of their seeds after storage.
\end{abstract}

Index terms: Passiflora edulis, genotypes, seeds, vigor, stress oxidative.

\section{PEROXIDAÇÃO LIPÍDICA E EMERGÊNCIA EM SEMENTES DE PROGÊNIES DE MARACUJAZEIRO-AMARELO}

RESUMO - O objetivo foi avaliar a porcentagem de emergência de plântlulas e a peroxidação lipídica de sementes de 29 progênies de meio-irmãos do maracujazeiro- amarelo (Passiflora edulis Sims.), após 24 meses sob armazenamento. O delineamento experimental foi o inteiramente casualizado, com quatro repetições de 50 sementes cada, a partir do qual os tratamentos foram as progênies $(1,2,3,4,5,6,7,8,9$, $10,11,12,13,14,15,16,17,18,19,20,21,22,23,24,25,26,27,28$ e 29). A avaliação da porcentagem de emergência das plântulas foi realizada aos 14 e 28 dias após a semeadua. A peroxidação lipídica das sementes foi expressa como conteúdo de malondialdeído (MDA), que foi determinado pelo método de TBARS. Aproximadamente $21 \%$ das progênies de meios-irmãos mantiveram a viabilidade de suas sementes para 24 meses de armazenamento. Os resultados apontam para uma variabilidade genética quanto ao vigor e á emergência de plântulas de maracujazeiro-amarelo, com ocorrência de indivíduos com alta e outros com baixa capacidade de manter a qualidade fisiológica de suas sementes após o armazenamento.

Termos para indexação: Passiflora edulis, genótipos, sementes, vigor, estresse oxidativo.

\footnotetext{
${ }^{1}$ (Trabalho 030-12). Recebido em: 04-01-2012. Aceito para publicação em: 27-06-2012.

${ }^{2}$ Instituto Federal do Espírito Santo, Campus Ibatiba-ES, Av 7 de novembro, s/n, Centro, 29395-000. E-mail: joaopaulobestete@gmail.com ${ }^{3}$ Universidade Federal do Espírito Santo (UFES), Centro Universitário Norte do Espírito Santo (CEUNES), Departamento de Ciências Agrárias e Biológicas (DCAB), Rodovia BR 101 Norte, Km 60, Bairro Litorâneo, 29932-340, São Mateus-ES. E-mail: rodrigo $\neg$ sobreiraalexandre@gmail.com

${ }^{4}$ Embrapa Acre, Centro de Pesquisa Agroflorestal do Acre, Rodovia BR 364, Km 14, Zona Rural, Caixa Postal 321, 69908-970, Rio Branco-AC, Brasil

${ }^{5}$ Universidade Federal do Espírito Santo (UFES), Centro de Ciências Agrárias (CCA), Alto Universitário, s/n, 29200-000, Alegre-ES, Brasil

${ }^{6}$ Universidade Federal de Viçosa (UFV), Centro de Ciências Agrárias, Departamento de Fitotecnia, Av. PH Rolfs, 36570-000, Viçosa-MG, Brasil
} 


\section{INTRODUCTION}

Passiflora edulis, the passion fruit native from Brazil, has several common names (such as sour passion fruit, yellow passion fruit, black passion fruit, and purple passion fruit), and presents a wide variability (BERNACCI et al., 2008). Among those species, the yellow passion fruit plant $P$. edulis Sims. f. flavicarpa Deg. is most commercially explored. Numerous uses are attributed to this species as sedative activity (DENG et al., 2010; LI et al., 2011). In addition to its seeds serve as a vehicle for induction of resistance in the yellow passion fruit Xanthomonas axonopodis pv. passiflorae (BORO et al., 2011). High genetic variability is found in the Passiflora genus. Alexandre et al. (2009) report the importance in using the natural genetic variability of the commercial species $P$. edulis f. flavicarpa in genetic improvement programs. Alexandre et al. (2004) and Negreiros et al. (2008) found genetic variability affecting both percent germination and emergency speed in Passiflora edulis f. flavicarpa.

The seed storage is important to provide either more flexibility to its commercialization and the germplasm preservation. The need to conserve plant genetic resources can no longer be in doubt. Genetic resources are vital for crop breeding programmes as sources of new genes for, for example, disease and pest resistance (PRACIAK, 2008). On the other hand, the storage for long times may affect the viability of the seeds and even causing their death, which could be detected through several physiologic and biochemical mechanisms. Among those indicators, one may find the formation of cytotoxic substances such as the production of the malondialdehyde (MDA) that is a product of the lipid peroxidation. The peroxidation of the lipid membranes causes decrease in fluidity and modifications in both ion permeability and other functions associated to the membranes (QUEIROZ et al., 1998). Some studies show the possibility of early identification of genotypes tolerant to stresses by means of biochemical and molecular markers (MA et al., 2007; MEI et al., 2010; KAUR et al., 2012). In general high superoxide dismutase (SOD) activity, and $\mathrm{H}_{2} \mathrm{O}_{2}$ content and low MDA and phytic acid content are related with cold stress tolerance (KAUR et al., 2012). Cruz et al. (2007) ranked genotypes for seed tolerance to low temperatures, showing that there is variability between them and potential for use in earlier sowing in southern Brazil.

The objective was to evaluate the percentage of emergency plantlets and lipid peroxidation in seeds of 29 half-sib progenies of yellow passion fruit (Passiflora edulis Sims.) after 24 months under storage.

\section{MATERIAL AND METHODS}

The experiment was conducted in the Laboratory of Technology and Seed Analysis of the Plant Sciences Department, University Center of Northern Espírito Santo (CEUNES) of Federal University of Espírito Santo (UFES), Alegre-Espírito Santo.

Ripe fruits of only one yellow passion fruit plant (Passiflora edulis Sims.) (BERNACCI et al., 2008) obtained by open pollination of 29 half-sib progenies in the orchard at the Horticulture Sector of the Experimental Farm of the Plant Sciences Department, Federal University of Viçosa, ViçosaMinas Gerais.

The seeds were extracted, by half-sectioning of the fruits and removing the mucilage containing the seeds from their internal cavity. Mucilage was separated from the seeds, by using a thin-meshed sieve added with quicklime $(\mathrm{CaO})$ and subjected to friction with the hands on such a way to remove the aril. Then, the seeds were washed in running water for final removal of the placenta remains. After completely clean and rinsed, they were arranged on paper towel and left to dry under shadow for three days. The seeds were conditioned in paper multifoliated bags and stored in refrigerator at $5^{\circ} \mathrm{C}$ temperature for twenty-four months.

Following, they were sowed in gerbox boxes containing sterilized sand as substratum at $1 \mathrm{~cm}$ depth and incubated in BOD-type germination chamber provided with fluorescent tubes of $40 \mathrm{~W}\left(\right.$ OSRAM $^{\circledR}$, Daylight), so promoting an irradiance of $30 \mu \mathrm{mol} \mathrm{m}^{-2}$ $\mathrm{s}^{-1}$ and photoperiod of 12/12 hours (light/dark) under alternate temperature of $20-30{ }^{\circ} \mathrm{C}$. When necessary, the substrate was dipped up to field capacity. The evaluation of the percent plantlet emergency was accomplished at 14 and 28 days after sowing.

The lipid peroxidation of the seeds were expressed as malondialdehyde (MDA) content, that was determined by the TBARS method (BUEGE \& AUST, 1978; MA et al., 2007; MEI et al., 2010; YANG et al., 2010; KAUR et al., 2012; KESHAVKANT et al., 2012). Samples of seeds within each progeny (100mg fresh matter) were homogenized in $5.0 \mathrm{~mL}$ trichloroacetic acid (TCA) $0.1 \%(\mathrm{p} / \mathrm{v})$ at the presence of polyvinylpolypyrholidon (PVPP) at the proportion of 1:1.5 (PMF:PVPP). The homogenate was centrifuged for 30 minutes at $4000 \mathrm{~g}$. All stages necessary to the extraction process were conducted at $4{ }^{\circ} \mathrm{C}$ temperature. Some $1.0 \mathrm{~mL}$ aliquot was taken 
from the supernatant, by adding to it an aliquot of $4.0 \mathrm{~mL}$ of the mixture containing $10 \%(\mathrm{p} / \mathrm{v})$ of TCA and $0.5 \%$ TBA containing $0.01 \%$ BHT (butylhydrotoluene). Then, the test tubes containing the mixture were closed and incubated in water-bath for 15 minutes at $95{ }^{\circ} \mathrm{C}$ with agitation. The reaction was interrupted by transferring the test tubes to ice bath. The "white" was prepared without the sample, but following all other stages. The absorbance of the supernatant was read at $535 \mathrm{~nm}$ and $600 \mathrm{~nm}$. The formed amount of the MDA-TBA compound was determined, by applying the methodology described by Dhindsa et al. (1981), according to the equation: [MDA $\left.]=\left(\mathrm{A}_{535}-\mathrm{A}_{600}\right) / \xi \cdot \mathrm{b}\right)$, where $\xi$ (extinction coefficient) $=1.56 \times 10^{-5} \mathrm{~mol}^{-1} \mathrm{~cm}^{-1}$ and $\mathrm{b}$ (optic length) $=1 \mathrm{~cm}$.

The completely randomized design was used, where the treatments were those 29 half-sib progenies (1-29), with four replicates with 50 seeds each one. The data were subjected to variance analysis, with the averages grouped by the Scott-Knott grouping test, at $5 \%$ probability.

\section{RESULTS AND DISCUSSION}

At 14 days under evaluation, only progenies 9 and 14 showed emergency percentage above 50\%. However, progeny 9 showed low vigor (54\%) when compared to progeny 14 that reached $71 \%$ emergency of the plantlets (Figure 1). Because this genetic influence, there is no possibility to characterizing this passion fruit plant as a highly vigorous species. In this study, only progeny 14 showed the best result also for this characteristic (Figure 1).

At 28 days, the highest emergency percentage (97\%) was found in progeny 14 . The progenies $2,9,13,21$ and 24 showed the values $82 \%, 84 \%$, $81 \%, 92 \%$ and $94 \%$, respectively, so not statistically differing from progeny 14 that belongs to the same grouping according to Scott-Knott test (Figure 1). From those 29 progenies under study, 17 showed lower emergency percentage (1-32\%; 3- 1\%; 4- 45\%; 7- 4\%; 8- 30\%; 10- 9\%; 11- 27\%; 17- 25\%; 18-32\%; 19- 9\%; 22- 42\%; 23- 49\%; 26- 46\%; 27- 47\%; $28-$ $47 \%$ ) whereas two ones (5 and 25 ) equal to $50 \%$. It was also observed that four progenies $(6,12,20$ and 29) showed no plantlet emergence (Figure 1). The other progenies 15 (57\%) and 16 (61\%) also showed low emergency percentage (Figure1). Those results point out the occurrence of effect from the genetic material origin and, in this case, only six $(2,9,13$, 14, 21 and 24) of the 29 progenies under study kept high viability of the seeds.

Alexandre et al. (2004) also verified that speed and emergency percentage of the plantlets were affected by the genotype. Second (NEGREIROS et al., 2008), among the features that contributed most to genetic diversity has been the emergence percentage and emergence speed index. Moreover, control of the male progenitor did not influence the seed quality (ARAÚJO et al., 2009).

Alexandre et al. (2004) observed that progeny 33 showed the highest vigor and emergency (84\%) results of the plantlets. Because they developed the study under field conditions, the climatic variations occurring during the experiment might have been the factor limiting a high genotype numbers to reach higher values for emergency of the plantlets, despite the seeds have not been subjected to storage. In the present study, however, a higher number of progenies are observed with high emergency percentage, since the environmental conditions were so controlled as possible, mainly the temperature $\left(20-30{ }^{\circ} \mathrm{C}\right)$. The likely explanation for the low emergence of some progeny may be genetic, as observed by (MARTINS et al., 2010), where he found in the seeds of $P$. edulis f. flavicarpa the presence of steroids, triterpenoid and reducing sugars which may inhibit or reduce germination.

When conditioning the seeds of the progenies for 12 months in permeable paper bags and to store them under laboratory conditions $\left(25^{\circ} \mathrm{C}\right)$, Alexandre (2006) observed that progeny 2 reached the highest germination percentage (61\%) at the end of this period. In this case, the low germination values of the seeds from those progenies are probably related to storage conditions. Second (CARLESSO et al., 2008) storage for three and six months did not affect the physiological quality of seeds. It is well-known that storage highly affects the physiologic quality of the seeds, so the storage environmental conditions in the present study (refrigerator at $5{ }^{\circ} \mathrm{C}$ ) probably provided higher number of progenies with high emergency rate (Figure 1).

According to Nakagawa et al. (1981), the best results for preservation of the yellow passion fruit seeds showing $60 \%$ germination after 57 months under storage are due to low temperature $\left( \pm 5^{\circ} \mathrm{C}\right)$. Catunda et al. (2003) found that those yellow passion fruit seeds stored in refrigerator $\left(4^{\circ} \mathrm{C}\right.$ and $\left.60 \% \mathrm{RH}\right)$ showed better viability preservation, independent from the packing type used. However, Martins et al. (2005) observed that combining 10\% moisture level with $20{ }^{\circ} \mathrm{C}$ temperature favored the preservation of the $P$. edulis f. flavicarpa seeds at 315 days under storage. In this condition, they found 79.5\% emerged plantlets. Although the best emergency results for the plantlets (51 and 43\%, respectively) of P. edulis 
f. flavicarpa were obtained when the seeds of this species were stored in chambers with controlled temperature $\left(15{ }^{\circ} \mathrm{C} ; 7\right.$ and $\left.11 \% \mathrm{RH}\right)$, Fonseca and Silva (2005) observed the values to be very low, so pointing out low efficiency of the treatments in maintaining the physiologic potential of the seeds.

The highest MDA contents observed in seeds of the progenies 3, 6, 7, 12, 20 and 29 (Figure 2) can explain the values below 5\% found in the emergency of the plantlets from progenies 3 and 7, but null in those from progenies 6, 12, 20 and 29 (Figure 1). MDA is a biomarker that induces oxidative damages and one of the last products released in the lipoperoxidation process. Lipoperoxidation is a chained autoxidation between the molecular oxygen and the polyunsaturated fatty acids of the phospholipid membranes (MATIAS \& CREPPY, 1998). Comparisons between levels of this aldehyde in seeds of $P$. edulis indicate the possibility of selecting genotypes tolerant to stress in storage. Seeds of commercial species (P. edulis f. flavicarpa, $P$. edulis and $P$. alata) are rich in polyunsaturated fatty acids (ZERAIK et al., 2010). This process occurs even though these polyunsaturated fatty acids found in large quantities, for example, in $P$. edulis are less susceptible to oxidation (LOPES et al., 2010).

The MDA concentrations found by Alexandre (2006) in seeds of the P. edulis f. flavicarpa progenies stored under laboratory conditions (25 ${ }^{\circ} \mathrm{C}$ ) for twelve months were considerably higher than those observed in the present study, from which the seeds were stored in refrigerator $\left(5^{\circ} \mathrm{C}\right)$, despite the storage period to be longer (twenty-four months). The storage of the seeds in refrigerator at $5{ }^{\circ} \mathrm{C}$ has probably reduced the metabolism of the seeds, consequently also reduced the deteriorative process, where Alexandre (2006) obtained an average of 3.19 nmol $\mathrm{gMF}^{-1}$ (MDA) and the present study the values were below $1.8 \mathrm{nmol}^{-1} \mathrm{gMF}^{-1}$ (Figure 1).

Tozzi \& Takaki (2011) showed that lipids present mainly in the endosperm of seeds of $P$. edilis f. flavicarpa are used as a reserve. And what that inositol phospholipids play an important role the trafficking of membranes, the phytic and biosynthesis and cell wall, are obtained through the conversion of D-glucose-6-phosphate to 1-L-myoinositol-1-phosphate catalyzed by enzyme myoinositol-1-L-phosphate synthase (MIPS) was also isolated from $P$. edulis f. flavicarpa by cloning the gene PeMIPS1 (ABREU \& ARAGÃO, 2007).

It is known that lipid degradation in plants lead to the production of Acetil Co-A, leading to sucrose synthesis by gluconeogenesis and therefore may be stocked as starch when its levels in the cytosol are high (GRAHAM, 2008; MURPHY et al., 2008). Sucrose is the predominant sugar but its content was not correlated with good storage. The content of raffinose as a mass fraction of total sugars and the magnitude of the glassy state showed positive correlations with storage stability. Apparently raffinose amplifies the magnitude of the glass signal and this in turn is associated with enhanced storability (BERNAL-LUGO \& LEOPOLD, 2008). In the seeds of Medicago truncatula stachyose was synthesized only during the final maturation and early desiccation (DJEMEL et al., 2005). However, in soybean oligosaccharides of the raffinose family is not an essential source of energy during germination (DIERKING \& BILYEU, 2011).

Freitas et al. (2006) found reduced lipid contents in the cotton seeds, when the artificial aging of the seeds were increased. According to the authors, this reduction would be explained by the occurrence of oxidation in the lipids of the seeds that is a reaction caused by intensification in the deteriorative process. It is well-known that there are the occurrence of the enzymatic systems able to preventing the propagation of the free radical reactions is well-known, such as the case of the superoxide dismutase enzyme (SOD) that catalyzes the reaction $\mathrm{O}_{2} \cdot$ in $\mathrm{H}_{2} \mathrm{O}_{2}$ and the catalase enzyme (CAT) that transforms $\mathrm{H}_{2} \mathrm{O}_{2}$ into water and oxygen (MATIAS \& CREPPY, 1998). This mechanism could explain the low MDA values found in seeds of the progenies $2,5,9,13,14,15,16,21$, $23,24,25,26,27$ and 28, therefore suggesting higher activity of these enzymes from the oxidative stress.

A wide genetic variability occurs in vigor and emergence of the plantlets among different half-sib progenies of the yellow passion fruit plant, from which some genotypes show high capacity to maintaining the physiologic quality of their seeds, whereas other ones show low capacity after twentyfour months under storage. 


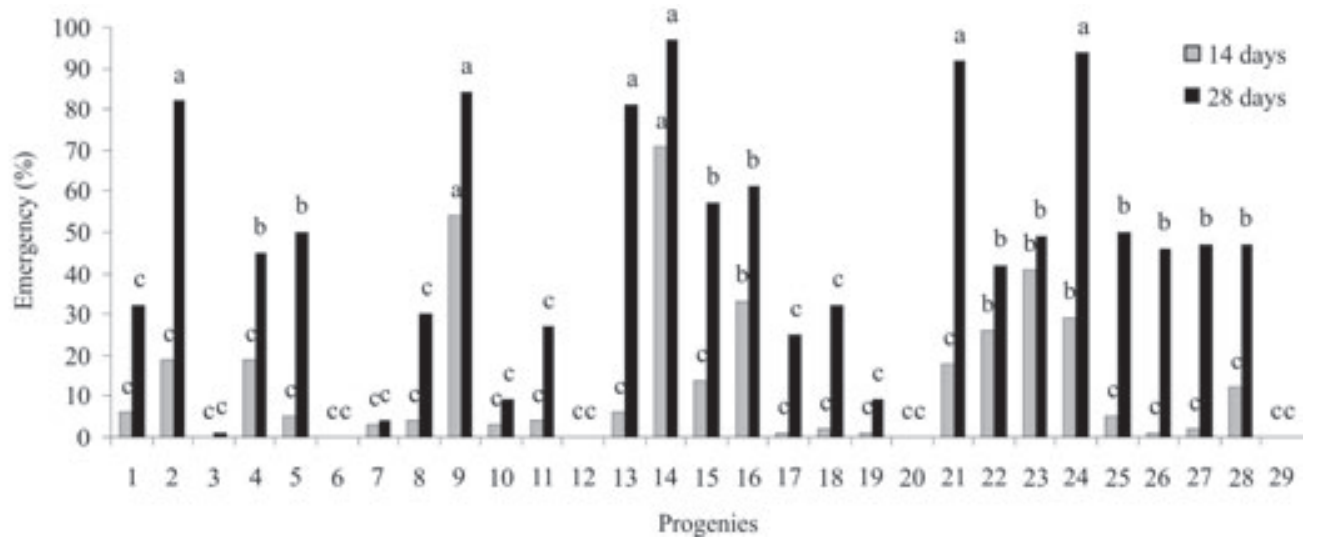

FIGURE 1 - Emergency of plantlets from 29 half-sib progenies of Passiflora edulis, after twenty-four months under storage. Averages with the same lower case letter among progenies belong to the same grouping, according to Scott-Knot test, at 5\% probability.

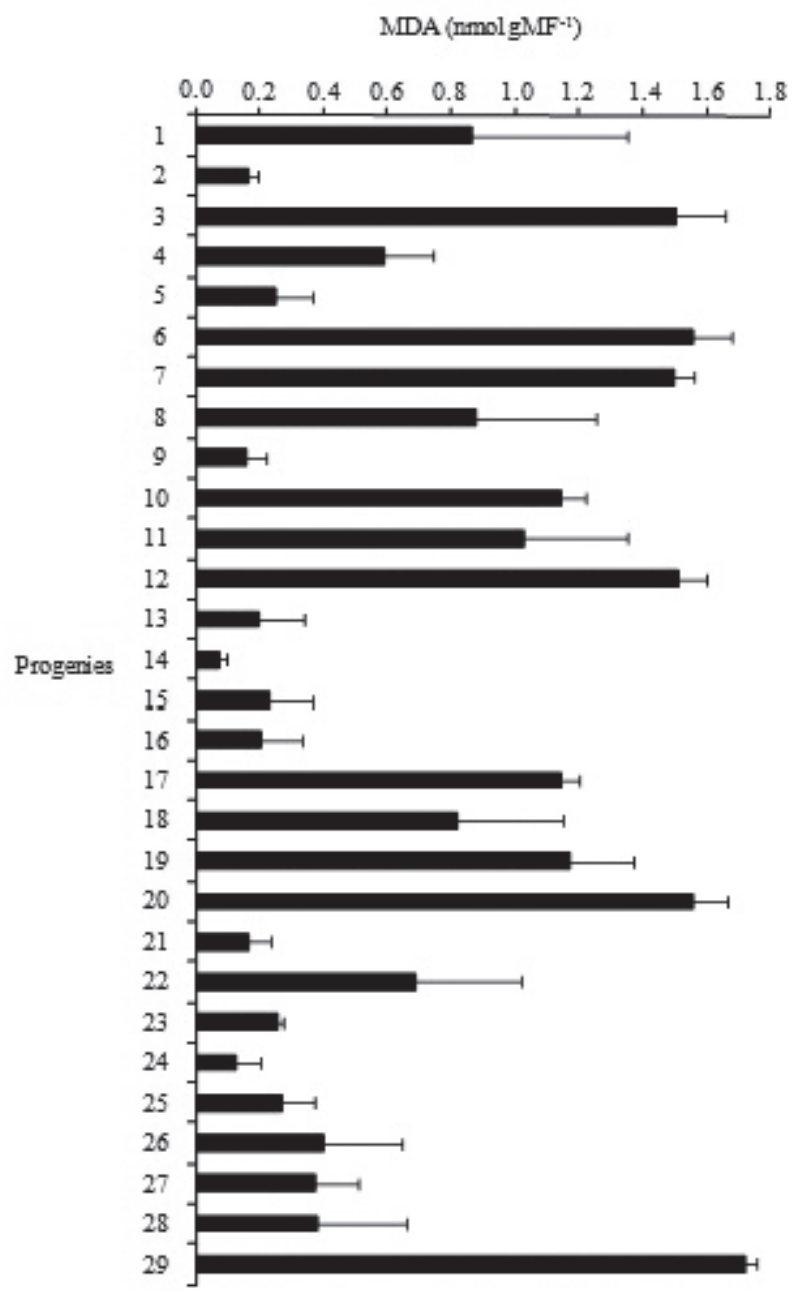

FIGURE 2 - Peroxidation of lipids (MDA content) in seeds from 29 half-sib progenies of Passiflora edulis at twenty-four months under storage. The bars correspond to the standard deviation of the average. 


\section{CONCLUSION}

A wide genetic variability occurs in vigor and emergence of the plantlets among different halfsib progenies of the yellow passion fruit plant, from which some genotypes show high $(2,9,13,14,21$ and 24) capacity to maintaining the physiologic quality of their seeds, whereas other ones show low $(1,3,6$, $7,8,10,11,12,17,18,19,20$ and 29) capacity after twenty-four months under storage.

\section{ACKNOWLEDGES}

To CNPq and CAPES for the granted scholarships; to Federal University of Espírito Santo for availability of the infrastructure during the accomplishment of the experiment and to the Federal University of Viçosa for the technical support in the lipid peroxidation analyses.

\section{REFERENCES}

ABREU, E.F.M.; ARAGÃO, F.J.L. Isolation and characterization of a myo-inositol-1-phosphate synthase gene from yellow passion fruit (Passiflora edulis f. flavicarpa) expressed during seed development and environmental stress. Annals of Botany, Oxford, v.99, p.285-292, 2007.

ALEXANDRE, R.S. Fatores de estresse na germinação de sementes e na propagação in vitro de Passiflora edulis Sims f. flavicarpa Degener. 2006. $166 \mathrm{f}$. Tese (Doutorado) - Universidade Federal de Viçosa, Viçosa, 2006.

ALEXANDRE, R.S.; BRUCKNER, C.H.; LOPES, J.C. Seleção de matrizes e comportamento do maracujazeiro quanto aos métodos de propagação. In: ALEXANDRE, R.S.; BRUCKNER, C.H.; LOPES, J.C. Propagação do maracujazeiro: aspectos morfológicos, fisiológicos e genéticos. Alegre: EDUFES, 2009. p.15-24.

ALEXANDRE, R.S.; WAGNER JÚNIOR, A.; NEGREIROS, J.R.S.; PARIZZOTTO, A.; BRUCKNER, C.H. Germinação de sementes de genótipos de maracujazeiro. Pesquisa Agropecuária Brasileira, Brasília, v.39, p.1.239-1.245, 2004.

ARAÚJO, E.C.; SILVA, R.F.; BARROSO, D.G.; CARVALHO, A.J.C. Efeito do armazenamento e do progenitor masculino sobre a qualidade e micromorfologia de sementes de maracujá. Revista Brasileira de Sementes, Londrina, v.31, p.110-119, 2009.
BERNACCI, L.C.; SOARES-SCOTT, M.D.; JUNQUEIRA, N.T.V.; PASSOS, I.R. da S.; MELETTI, L.M.M. Passiflora edulis Sims: the correct taxonomic way to cite the yellow passion fruit (and of others colors). Revista Brasileira de Fruticultura, Jaboticabal, v.30, n.2, p.566-576, 2008.

BERNAL-LUGO, I.; LEOPOLD, A.C. Seed stability during storage: raffinose content and seed glassy state. Seed Science Research, Cambridge, v.5, n.2, p.75-80, 2008.

BORO, M.C.; BERIAM, L.O.S.; GUZZO, S.D. Induced resistance against Xanthomonas axonopodis pv. passiflorae in passion fruit plants. Tropical Plant Pathology, Brasília, v.36, n.2, p.74-80, 2011.

BUEGE, J.A.; AUST, S.D. Microsomal lipid peroxidation. Methods in Enzymology, Pasadena, v.52, p.302-310, 1978.

CARLESSO, V.O.; BERBET, P.A.; SILVA, R.F.; DETMANN, E. Secagem e armazenamento de sementes de maracujá-amarelo (Passiflora edulis Sims f. flavicarpa Degener). Revista Brasileira de Sementes, Brasília, v.30, p.65-74, 2008.

CATUNDA, P.H.A.; VIEIRA, H.D.; SILVA, R.F.; POSSE, S.C.P. Influência do teor de água, da embalagem e das condições de armazenamento na qualidade de sementes de maracujá-amarelo. Revista Brasileira de Sementes, Brasília, v.25, p.65-71, 2003.

CRUZ, H.L. da; FERRARI, C. dos S.; MENEGHELLO, G.E.; KONFLANZ, V.; ZIMMER, P.D.; VINHOLES, P. da S.; CASTRO, M.A. da S. de. Avaliação de genótipos de milho para semeadura precoce sob influência de baixa temperatura. Revista Brasileira de Sementes, Brasília, v.29, n.1, p.52-60, 2007.

DENG, J.; ZHOU, Y.; BAI, M.; LI, H.; LI, L. Anxiolytic and sedative activities of Passiflora edulis f. flavicarpa. Journal of Ethnopharmacology, Leiden, v.128, p.148-153, 2010.

DHINDSA, R.S.; PLUMB-DHINDSA, P.; THORPE, T.A. Leaf senescence: correlated with increased levels of membrane permeability and lipid peroxidation, and decreased levels of superoxide dismutase and catalase. Journal of Experimental Botany, Lancaster, v.32, p.93-101, 1981. 
DIERKING, E.C.; BILYEU, K.D. Raffinose and stacyose metabolism are not required for efficient soybean seed germination. Journal of Plant Physiology, Leipzig, v.166, p.1.329-1.335, 2011.

DJEMEL, N.; GUEDON, D.; LECHEVALIER, A.; SALON, C.; MIQUEL, M.; PROSPERI, J-M.; ROCHAT, C.; BOUTIN, J-P. Development and composition of the seeds of nine genotypes of the Medicago truncatula species complex. Plant Physiology and Biochemistry, Bari, v.43, n.6, p.557-566, 2005.

FONSECA, S.C.L.; SILVA, W.R. Conservação de sementes de maracujá-amarelo: interferências no teor de água das sementes e da temperatura de armazenamento. Bragantia, Campinas, v.64, p.273-289, 2005.

FREITAS, R.A.; DIAS, D.C.F.S.; DIAS, L.A.S.; OLIVEIRA, M.G.A.; JOSÉ, I.C. Alterações fisiológicas e bioquímicas em sementes de algodão submetidas ao envelhecimento artificial. Bioscience Journal, Uberlândia, v.22, p.67-76, 2006.

GRAHAM, I.A. Seed storage oil mobilization. Annual Review of Plant Physiology, Palo Alto, v.59, p.115-142, 2008.

KAUR, S.; ARORA, M.; GUPTA, A.K.; KAUR, N. Exploration of biochemical and molecular diversity in chickpea seeds to categorize cold stress-tolerant and susceptible genotypes. Acta Physiologiae Plantarum, Aarhus, v.34, n.2, p.569-580, 2012.

KESHAVKANT, S.; PADHAN, J.; PARKHEY, S.; NAITHANT, C. Physiological and antioxidant responses of germination Cicer arietinum seeds to salt stress. Russian Journal of Plant Physiology, Heidelberg, v.59, n.2, p.206-211, 2012.

LI, H.; ZHOU, P.; YANG, Q.; SHEN, Y.; DENG, J.; LI, L.; ZHAO, D. Comparative studies on anxiolytic activities and flavonoid compositions of Passiflora edulis 'edulis' and Passiflora edulis 'Alavicarpa'. Journal of Ethnopharmacology, Leiden, v.133, p.1.085-1.090, 2011.

LOPES, R.M.; SEVILHA, A.C.; FALEIRO, F.G.; SILVA, D.B.; VIEIRA, R.F.; AGOSTINI-COSTA, T. da $\mathrm{S}$. Estudo comparativo do perfil de ácidos graxos em semente de Passifloras nativas do cerrado brasileiro. Revista Brasileira de Fruticultura, Jaboticabal, v.32, n.2, p.498-506, 2010.
MA, B.; WAN, JIANMIN; SHEN, Z. $\mathrm{H}_{2} \mathrm{O}_{2}$ production and antioxidant responses in seeds and early seedlings of two different rice varieties exposed to aluminum. Plant Growth Regulation, Berlin, v.52, n.1, p.91-100, 2007.

MATIAS, W.G.; CREPPY, E.E. Lipoperoxidação induzida pelo ácido okadaíco: uma toxina marinha. Revista Biotecnologia Ciência \& Desenvolvimento, Brasília, v.4, p.40-44, 1998.

MARTINS, C.M.; VASCONCELLOS, M.A.S.; ROSETTO, C.A.V.; CARVALHO, M.G. Prospecção fitoquímica do arilo de sementes de maracujá-amarelo e influência em germinação de sementes. Ciência Rural, Santa Maria, v.40, p.1.934-1940, 2010.

MARTINS, L.; SILVA, W.R.; MELETTI, L.M. Conservação de sementes de maracujá-amarelo (Passiflora edulis Sims f. flavicarpa Deg.). Revista Brasileira de Sementes, Londrina, v.27, p.183-189, 2005.

MEI, Y.; SONG, S. Response to temperature stress of reactive oxygen species scavenging enzymes in the cross-tolerance of barley seed germination. Journal of Zhejiang University - Science B, Hangzhou, v.11, n.2, p.965-972, 2010.

MURPHY, D.J.; RAWSTHORNE, S.; HILLS, M.J. Storage lipid formation in seeds. Seed Science Research, Cambridge, v.3, n.2, p.79-95, 2008.

NAKAGAWA, J.; CAVARIANI, C.; AMARAL, W.A.N. Armazenamento de sementes de maracujá-amarelo. Revista Brasileira de Sementes, Brasilia, v.13, p.77-80, 1981.

NEGREIROS, J.R.S.; ALEXANDRE, R.S.; ÁLVARES, V.S.; BRUCKNER, C.H.; CRUZ, C.D. Divergência genética entre progênies de maracujazeiro-amarelo com base em características das plântulas. Revista Brasileira de Fruticultura, Jaboticabal, v.30, p.197-201, 2008.

PRACIAK, A. Seed storage of plant genetic resources. Seed Science Research, Cambridge, v.6, n.2, p.71-75, 2008.

QUEIROZ, C.G.S.; ALONSO, A.; MARESGUIA, M.; MAGALHÃES, A.C. Chilling-induced changes in membrane fluidity and antioxidant enzyme activities in Coffea arabica L. roots. Biology Plantarum, Prague, v.41, p.403-413, 1998. 
TOZZI, H.H.; TAKAKI, M. Histhochemical analysis of seed reserve mobilization in Passiflora edulis Sims fo. Alavicarpa O. Deg. (yellow passion fruit) during germination. Brazilian Journal of Biology, São Carlos, n.71, n.3, p.701-708, 2011.

ZERAIK, M.L.; PEREIRA, C.A.M.; ZUIN, V.G.; YARIWAKE, J.H. Maracujá: um alimento funcional? Revista Brasileira de Farmacognosia, Curitiba, v.20, n.3, p.459-471, 2010.
YANG, Y.; LIU, Q.; WANG, G.X.; WANG, X.D.; GUO, J.Y. Germination, osmotic adjustment, and antioxidant enzyme activities of gibberelin-preteated Picea asperata seeds under water stress. New Forests, Dordrecht, v.39, n.2, p.231-243, 2010. 